\title{
Protective Effect of Vitamin B5 (Dexpanthenol) on Nephropathy in Streptozotocin Diabetic Rats
}

\author{
Sıçanlarda B5 Vitamininin (Dekspantenol) Nefropatiye Etkisi \\ (1) Nazli Gulriz Ceri ${ }^{1}$, (1) Kanat Gulle ${ }^{2}$, (1) Mehmet Arasli ${ }^{3}$, (1) Meryem Akpolat $^{4}$, (1) Buket Demirci ${ }^{5}$ \\ ${ }^{1}$ Aydın Adnan Menderes University Faculty of Medicine, Department of Anatomy, Aydın, Turkey \\ ${ }^{2}$ Süleyman Demirel University Faculty of Medicine, Department of Histology and Embryology, Isparta, Turkey \\ ${ }^{3}$ Zonguldak Bülent Ecevit University Faculty of Medicine, Department of Immunology, Zonguldak, Turkey \\ ${ }^{4}$ Zonguldak Bülent Ecevit University Faculty of Medicine, Department Histology and Embryology, Zonguldak, Turkey \\ ${ }^{5}$ Aydın Adnan Menderes University Faculty of Medicine, Department of Medical Pharmacology, Aydın, Turkey
}

Keywords

Cytokines, panthenol, pantothenic acid, pantothenol, streptozotocin

\section{Anahtar Kelimeler}

Sitokinler, panthenol, pantotenik asit, pantotenol, streptozotosin

Received/Geliş Tarihi : 23.01.2021

Accepted/Kabul Tarihi : 27.01.2021

doi:10.4274/meandros.galenos.2021.65002

Address for Correspondence/Yazışma Adresi: Nazli Gulriz Ceri MD,

Aydın Adnan Menderes University Faculty of Medicine, Department of Anatomy, Aydın, Turkey

Phone : +90 5335659868

E-mail : drnazligulrizceri@gmail.com

ORCID ID: orcid.org/0000-0001-5486-1824

(C) Meandros Medical and Dental Journal, Published by Galenos Publishing House.

This is article distributed under the terms of the

Creative Commons Attribution NonCommercial 4.0

International Licence (CC BY-NC 4.0).

\begin{abstract}
Objective: This study aimed to evaluate the effects of vitamin B5 [dexpanthenol, DEX] treatment on the kidney in a streptozotocin (STZ) diabetes animal model.

Materials and Methods: Twenty-four Wistar rats were randomised in one of the four groups: Group 1 served as control, and group 2 was administered high-dose DEX (300 $\mathrm{mg} / \mathrm{kg} / \mathrm{day}$ ) as a safety group. Diabetes was induced by intraperitoneal injection of a single dose of STZ ( $50 \mathrm{mg} / \mathrm{kg}$ ) in groups 3 and 4 . In group 4, DEX was administered as well. All groups were followed up for 6 weeks. Histopathological analyses were performed on renal tissue using periodic acid-Schiff and HematoxylinEosin stains.

Results: Microscopic evaluation of the kidney revealed that the rats demonstrated kidney damage 6 weeks after STZ administration. However, high-dose and longterm DEX administration alone did not damage renal tissue; moreover, kidney damage was prevented if DEX was administered in the early phase of diabetes.

Conclusion: DEX could be a safe and cost-effective vitamin for the prevention of diabetes complications.
\end{abstract}

Öz

Amaç: Çalışmamızda streptozotosin (STZ) diyabet hayvan modelinde B5 [dexpanthenol (DEX)] vitamini ile tedavinin böbrek üzerindeki etkilerini değerlendirdik.

Gereç ve Yöntemler: Yirmi dört wistar sıçanı dört gruba eşit ve randomize olarak dağıtıldı. Grup 1 kontrol grubu; grup 2 güvenlik grubu olarak yüksek doz DEX (300 $\mathrm{mg} / \mathrm{kg} / \mathrm{gün}$ ) verildi. Diyabet, grup 3 ve 4'te tek bir intraperitoneal doz STZ (50 mg/ $\mathrm{kg}$ ) enjeksiyonu ile oluşturuldu. Grup 4 DEX ile tedavi edildi. Tüm gruplar 6 hafta takip edildi. Periyodik asit Schiff ve Hematoksilen-Eosin kullanılarak böbrek dokusu üzerinde histopatolojik incelemeler yapıldı.

Bulgular: Böbreğin mikroskobik değerlendirmesinde, sıçanlarda STZ müdahalesinden 6 hafta sonra böbrek hasarı geliştiği görüldü. Tek başına yüksek ve uzun süreli DEX uygulaması böbrek dokusu için zararı değildi. Ayrıca diyabetin erken evresinde DEX verilmesi böbrek hasarını önledi.

Sonuç: Diyabet komplikasyonlarını önlemek için DEX güvenli ve uygun maliyetli bir vitamin olabilir. 


\section{Introduction}

Diabetic nephropathy (DN) is seen in approximately $40 \%$ of diabetic patients as being one of the major long-term microvascular complications (1). And characterized with high blood pressure, albuminuria and progressive renal damage that leads to end stage renal failure (2). Metabolic and hemodynamic factors were thought to be the main mechanisms of the diabetes and DN; however, it has been shown that chronic inflammation caused by immunologic and inflammatory mechanisms may have a significant role in the development and progression of the disease (3). Worldwide the number of diabetes patients and patients with DN, are highly increasing and more and more patients will unfortunately be experiencing endstage renal disease, therefore, it is highly important to investigate and prevent progressive renal disease with the effective treatments (1).

Streptozotocin (STZ) is the main chemical agent used for the induction of diabetic metabolic state in experimental animals $(4,5)$.

Most of the protective effects of pantothenic acid and its reduced derivative, dexpanthenol (DEX) (pantothenol, panthenol) are attributed to its modulator activity on antioxidant capacity (6-8). Decreased apoptosis rate (9), increased coenzyme A (10) and adenosine triphosphate (ATP) synthesis (11) have been reported as well. Bayrak et al. (12) have reported DEX might be a new therapeutic approach by reducing the inflammation and cell infiltration in interstitial cystitis. Meanwhile, increased rate of urinary excretion of pantothenic acid has been reported in both animal model and patients with diabetes in 1967 (4). Since then, the studies conducted regard to the matter of vitamin B5's effect on DN are scarcely close to none. In the present study, we investigated the effect of DEX supplementation on the reversal of STZ-induced DN in rats.

\section{Materials and Methods}

\section{Experimental Procedure}

Twenty-four male Wistar rats, each weighed 220$240 \mathrm{~g}$, were provided by Aydın Adnan Menderes University, Experimental Animal Center and all experiments were designed and done being in line with the principles and guidelines of Aydın Adnan
Menderes University Animal Ethics Committee's approval (decision no: HEK/2009/64, date: 02.09.2009). The animals were randomly divided in to four groups: The rats in the control group served as healthy animals and the DEX group has taken only intraperitoneal $300 \mathrm{mg} / \mathrm{kg}$ DEX once a day for six weeks. The other two groups have injected a single intraperitoneal dose of STZ $(50 \mathrm{mg} / \mathrm{kg}$ in $1 \mathrm{~mL}$ of saline). STZ applied rats with over than $200 \mathrm{mg} / \mathrm{dL}$ blood sugar levels (IME-DC ${ }^{\circledR}$ Glucosticks) $72 \mathrm{~h}$ after the injection were considered diabetic. STZ+DEX group was treated daily DEX $(300 \mathrm{mg} / \mathrm{kg}$ ) for six weeks as well. DEX doses of animals were adjusted every monday according to their weight changing during 6 weeks. Under the anaesthesia of ketamine and xylasine ( $50 \mathrm{mg} / \mathrm{kg}$ and $5 \mathrm{mg} / \mathrm{kg}$, respectively), kidney tissues were obtained and fixed in $10 \%$ neutral buffered formalin solution.

\section{Histological Assessment of Renal Tissue}

Kidney tissues embeded into paraffin and afterwards stained with hematoxylin and eosin and periodic acid Schiff (PAS). A bright-field microscope was used to examine these preparations and then photographs were taken (Carl Zeiss Axio Lab A1, Germany). Statistical analysis was not used in the study.

\section{Results}

We explained our results by dividing them into two groups histopathologically and histochemically

\section{Histopathological Findings}

In groups control and DEX-treated rats (Figure $1 A-B)$, normal renal tubular architecture and normal glomeruli were observed. In the STZ-treated rats (Figure 1C), it was observed that Bowman spaces of a number of glomeruli were narrowed, mesangial matrix was enlarged and tubular dilatations were seen. Additionally; falling of the epithelial cells to the lumens of tubules and Armanni-Ebstein lesions were determined. When compared, the renal structural alterations in STZ+DEX-treated (Figure 1D) rats, were less obvious than the untreated diabetic rats.

\section{Histochemical Findings}

When compared with control and DEX animals, in the renal histology in untreated diabetic rats, accelerated mesangial expansion, tubular dilatation, 
thickening of capsular basement membranes (CBMs), glomerular basement membranes (GBMs), and tubular basement membranes (TBMs) which are characterized by an increase in PAS-positive area, were observed (Figure 2A-B). When compared with untreated diabetic group, it is seen that the treatment of DEX, reduced the glomerular size; thickening of CBMs, GBMs, and
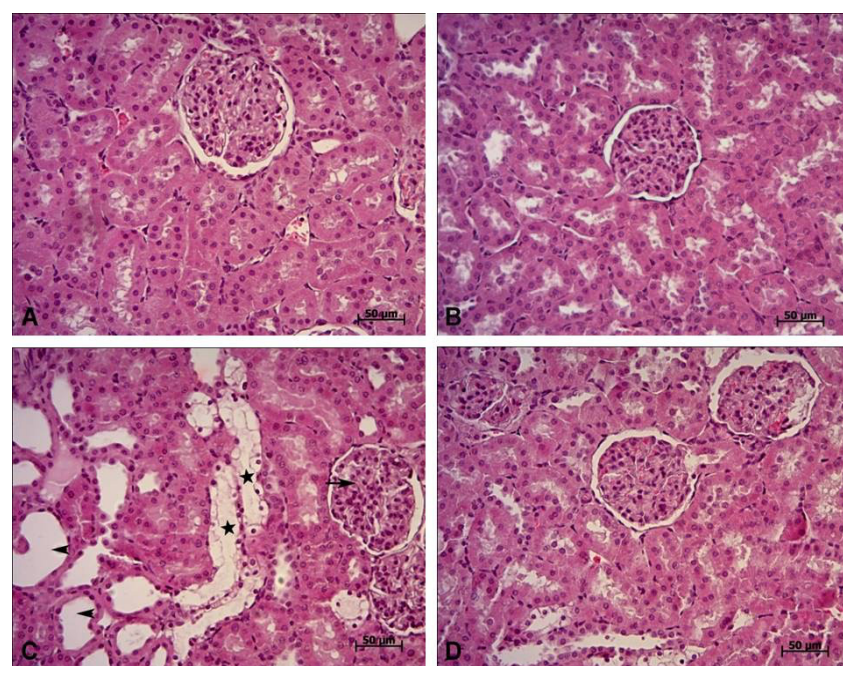

Figure 1. Representative micrographs of rat kidney sections stained with Hematoxylin-eosin. (A-B) Normal kidney morphology of control and DEX treated rats. (C) streptozotocintreated rats, showing mesangial matrix enlargement (arrow), tubular dilatations (arrowheads) and Armanni-Ebstein lesions (asterisks). (D) DEX-treated diabetic rats, close to normal architecture and low tubular damage. Scale bar, $50 \mu \mathrm{m}$

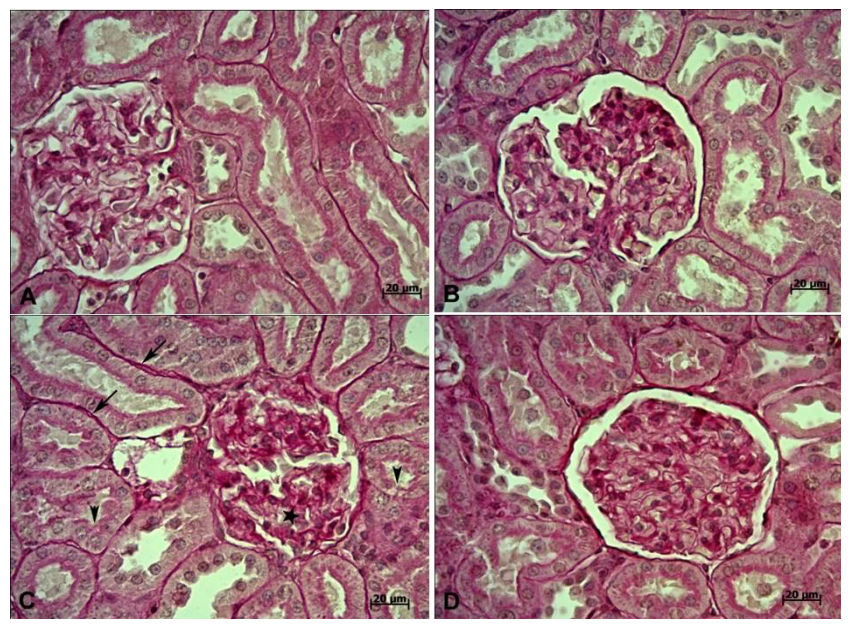

Figure 2. Pediatric acid Schiff (PAS) staining of kidney sections of control (A), dexpanthenol (DEX) (B), streptozotocin (STZ) (C), STZ+DEX (D) rats. In the STZ-treated group (C), increase in mesangial matrix (asterisk), thickening basal membranes (arrows), shorting and ruptures at the brush border (arrowheads) were seen. Scale bar, $20 \mu \mathrm{m}$.
TBMs; increased amounts of mesangial matrix; and tubular dilatation (Figure 2C-2D).

\section{Discussion}

In the present study, we considered the possibility that supplementation of DEX, a source of pantothenic acid, might prevent the kidney injury observed in STZ rats. Concerning this hypothesis, we have preferred to use pantothenic acid's high amount of dose to see its safety on the kidney. Histopathologic examination revealed that even if it is taken in long term and high dose, it does not show any adverse effect on the renal tissue. It has been investigated cardiovascular and liver effect of DEX, clinical and biochemical findings have been previously given $(13,14)$. Here, we particularly focused on histopathological evaluation on kidney for avoiding repeating of the data.

STZ is well accepted model of animal diabetes and the toxin can damage the kidney due to inhibition of glucose transporter expression (5). This study has been shown that 6-week was sufficient period to develop a remarkable injury following to the induction of STZ. Introducing treatment of DEX in the early phase of STZ diabetes was highly prevented the progression of DN. These results are in agreement with the previous literatures. One of earlier study about the relationship between diabetic kidney and pantothenic asid demonstrated the increased urinary loss of pantothenic acid and claimed that the body cannot use pantothenic acid for forming ATP; additional to vitamin B5 loss, some expelling mechanism might exist in the diabetic condition such as impaired renal tubular reabsorption of the vitamin or impaired conversion of pantothenic acid into its active form (4). The thickening of the basement membrane, hypertrophy of glomerular structures, and accumulation of extracellular matrix components are the major findings in DN (3). Replacement of depleted vitamin B5 stores lead to an improvement in histological findings such as tubular dilatation, thickening of glomerular and tubular basement membranes probably reducing oxidative stress. DEX protective effect has been reported in different animal model and on variety of tissues including kidney (15), liver (8) and testicular ischemia (7) and these studies explained and supported by improvement of biochemical parameters such as glutathione and malondialdehyde levels. Restoration 
of antioxidant defence system may help to improve inflammatory status, hence protects the kidney. Tutun et al. (16) publication also supports our findings that DEX protects the kidney from diabetes by increasing antioxidant activity.

It has been reported that increased infiltration of monocytes and macrophages and activated intrarenal lymphocytes in interstistitium are the underlying immunopathological mechanisms of DN $(2,3)$. DEX treatment has been found effective to reduce caspases level to prevent apoptosis and significantly decreased tubular necrosis (15) in renal ischemia-reperfusion injury. Additionally, has demonstrated intravesical DEX application reduce the inflammatory leukocytes and mast cells infiltration in animal model of chemical cystitis (12). Immunohistochemistry staining is required for further research to understand treatment effects of DEX especially on cytokine pathway.

\section{Conclusion}

The STZ diabetes model produce kidney damage within 6 weeks and DEX treatment protects the tissue from damage, at some point by regulating the inflammatory responses and oxidant status. DEX is well-tolerated and highly safe adjuvant therapy for preventing diabetes induced complications in kidney.

\section{Acknowledgements}

We want to thank to Gizem Sakalli.

Ethics

Ethics Committee Approval: Aydın Adnan Menderes University Animal Ethics Committee's approval for the study (decision no: HEK/2009/64, date: 02.09.2009).

Informed Consent: The study is an animal experiment.

Peer-review: Externally peer-reviewed.

\section{Authorship Contributions}

Concept: N.G.C., B.D., Design: N.G.C.., B.D., Supervision: N.G.C., B.D., Fundings: N.G.Ç., K.G., B.D., Materials: M.A., M.Ak., Data Collection or Processing: N.G.C., K.G., M.A., M.Ak., Analysis or Interpretation: N.G.C., M.A., M.Ak., B.D., Literature Search: N.G.C., K.G., M.A., M.Ak., B.D., Critical Review: N.G.Ç., B.D., Writing: N.G.C., K.G., M.A., M.Ak., B.D.

Conflict of Interest: No conflict of interest was declared by the authors.

Financial Disclosure: The authors declared that this study received no financial support.

\section{References}

1. Tomino Y, Cooper ME, Kurtz TW, Shimizu Y. Experimental models of type-2 diabetic nephropathy. Exp Diabetes Res 2012; 2012: 218917.

2. Moon JY, Jeong KH, Lee TW, Ihm CG, Lim SJ, Lee SH. Aberrant recruitment and activation of $\mathrm{T}$ cells in diabetic nephropathy. Am J Nephrol 2012; 35: 164-74.

3. Wu CC, Chen JS, Lu KC, Chen CC, Lin SH, Chu P, et al. Aberrant cytokines/chemokines production correlate with proteinuria in patients with overt diabetic nephropathy. Clin Chim Acta 2010; 411: 700-4.

4. Hatano M, Hodges RE, Evans TC, Hagemann RF, Leeper DB, Bean $W B$, et al. Urinary excretion of pantothenic acid by diabetic patients and by alloxan-diabetic rats. Am J Clin Nutr 1967; 20: 960-7.

5. Lenzen S. The mechanisms of alloxan- and streptozotocininduced diabetes. Diabetologia 2008; 51: 216-26.

6. Depeint F, Bruce WR, Shangari N, Mehta R, O'Brien PJ. Mitochondrial function and toxicity: role of the $B$ vitamin family on mitochondrial energy metabolism. Chem Biol Interact 2006; 163: 94-112.

7. Etensel B, Ozkisacik S, Ozkara E, Karul A, Oztan O, Yazici M, et al. Dexpanthenol attenuates lipid peroxidation and testicular damage at experimental ischemia and reperfusion injury. Pediatr Surg Int 2007; 23: 177-81.

8. Wojtczak L, Slyshenkov VS. Protection by pantothenic acid against apoptosis and cell damage by oxygen free radicals--the role of glutathione. Biofactors 2003; 17: 61-73.

9. Slyshenkov VS, Piwocka K, Sikora E, Wojtczak L. Pantothenic acid protects jurkat cells against ultraviolet light-induced apoptosis. Free Radic Biol Med 2001; 30: 1303-10.

10. Halvorsen $\mathrm{O}$, Skrede S. Regulation of the biosynthesis of $\mathrm{CoA}$ at the level of pantothenate kinase. Eur J Biochem 1982; 124: 211-5.

11. Slyshenkov VS, Dymkowska D, Wojtczak L. Pantothenic acid and pantothenol increase biosynthesis of glutathione by boosting cell energetics. FEBS Lett 2004; 569: 169-72.

12. Bayrak O, Seckiner I, Solakhan M, Karakok M, Erturhan SM, Yagci F. Effects of intravesical dexpanthenol use on lipid peroxidation and bladder histology in a chemical cystitis animal model. Urology 2012; 79: 1023-6.

13. Gulle K, Ceri NG, Akpolat M, Arasli M, Demirci B. The effects of dexpanthenol in streptozotocin-induced diabetic rats: histological, histochemical and immunological evidences. Histol Histopathol 2014; 29: 1305-13.

14. Demirci B, Demir O, Dost T, Birincioglu M. Protective effect of vitamin B5 (dexpanthenol) on cardiovascular damage induced by streptozocin in rats. Bratisl Lek Listy 2014; 115: 190-6.

15. Altintas R, Parlakpinar H, Beytur A, Vardi N, Polat A, Sagir M, et al. Protective effect of dexpanthenol on ischemia-reperfusioninduced renal injury in rats. Kidney Blood Press Res 2012; 36: 220-30.

16. Tutun B, Elbe H, Vardi N, Parlakpinar H, Polat A, Gunaltili M, et al. Dexpanthenol reduces diabetic nephropathy and renal oxidative stress in rats. Biotech Histochem 2019; 94: 84-91. 